\title{
Juridical Review Of The Granting Of Remissions To Prisoners Of Criminal Acts Of Corruption
}

\author{
Rizki Karina Azilia
}

Sumatera University Faculty Of Law. E-mail: rizkiazilia@gmail.com

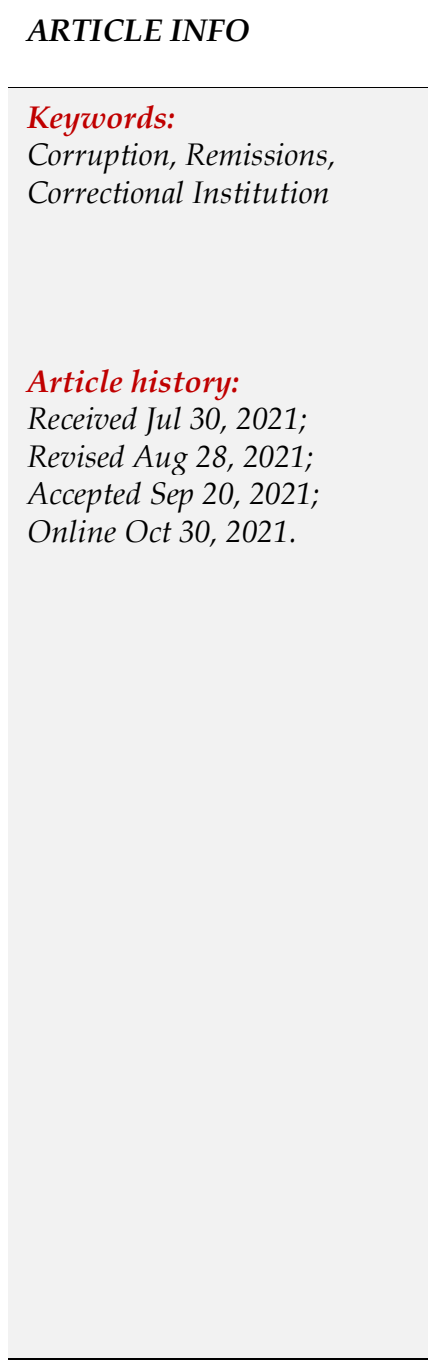

\begin{abstract}
Corruption has occurred systematically and widely, causing state financial losses, as well as violating the social and economic rights of the community at large. The most common punishment imposed on perpetrators of corruption is imprisonment. Law Number 12 of 1999 concerning Corrections states that one of the rights of prisoners is to obtain a reduction in their criminal period or remission, not least for prisoners who are perpetrators of corruption. The government has issued Government Regulation Number 28 of 2006 concerning the Terms and Procedures for the Implementation of the Rights of Correctional Inmates. Convicts of criminal acts of corruption can be given remission if they meet the requirements of good behavior and have served 1/3 (one third) of their criminal period. The study was conducted to find out the things that became the basis for granting remissions to prisoners, including convicts who were perpetrators of criminal acts of corruption and to find out how the legal arrangements for granting remissions to prisoners who were perpetrators of corruption in positive law in Indonesia. The type of research is normative juridical research. The data was collected through a literature study, and the data obtained were processed using qualitative data processing methods. This qualitative analysis is then linked to relevant problems and theories so that the data obtained are descriptive. The results of the analysis show that the correctional system seeks to realize the social reintegration of prisoners in prison, therefore the basis for granting remissions to prisoners is to motivate prisoners to behave well and accelerate prisoners who are well behaved so that they can be released and return to society before the actual date of freedom. The legal rules for granting remissions to convicts who commit corruption crimes are Government Regulation Number 28 of 2006, but have not been equipped with implementing regulations. The government should immediately provide clarity to this regulation by issuing implementing regulations so as to provide legal certainty for the Directorate General of Corrections.
\end{abstract}

This is an open access article under the CC BY-NC license.

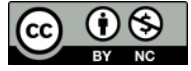

\section{Introduction}

Humans during their life always have various interests. An interest is an individual or group demand that is expected to be met. Humans as holders of interests as much as possible want their interests to be protected from dangers that threaten the fulfillment of these interests, but considering the many interests that are borne by a person, then in human interactions in society there are often conflicts, because in pursuit of personal interests sometimes can conflict with the interests of others. even harm others. 
This disturbance of interest or conflict cannot be allowed to continue, because it can cause an imbalance in the social order. Every time an imbalance occurs, it must be restored to its original state in order to create an orderly atmosphere, which is a guarantee of survival. The rule of law is needed to be a guide for human behavior so that in their interactions in society, they are bound by guidelines about what should be done or not, which if violated, the violator can be subject to sanctions.

The 1945 Constitution, both in its preamble and in its body, explicitly states that the State of Indonesia is a state of law. The law was created to create a peace based on harmony between order and peace. The purpose of the law will be achieved when there is harmony between legal certainty and legal comparability so as to produce justice. 3 Criminal law is part of the legal system or system of norms, and as a system, criminal law has the general nature of a system, namely comprehensive, has several elements, all elements are interrelated, and then form a structure.

Criminal law consists of norms that contain requirements and prohibitions which the legislators have associated with a sanction in the form of punishment, namely a special suffering. Criminal law can also be said as a system of norms that determine which actions and under what circumstances the punishment can be imposed, as well as what punishment can be imposed for these actions. Sources of criminal law in Indonesia are the Criminal Code, as well as criminal law rules outside the Criminal Code which are included in the Special Crimes Act, and various other laws and regulations.

Along with the development of world civilization, changes in every aspect of human life are also becoming more and more real. Along with that, the forms of crime also always follow the development of the times and are transformed into increasingly sophisticated forms, and with various modes. One of the criminal acts in Indonesia that is increasingly being discussed because the number is very large, carried out systematically and widely, and is detrimental not only to state finances but also violates the social and economic rights of the community at large so that it is classified as an extraordinary crime, is a criminal act of corruption. .

Corruption is rampant in various government activities related to the management or management in the form of receipts and expenditures of state money. The contributing factors include the lack of salary or income for Civil Servants compared to the needs that are increasing day by day, the cultural background or Indonesian culture which is the source or cause of widespread corruption, poor management and ineffective or efficient control, and modernization. ${ }^{6}$ The complexity of this criminal act of corruption requires not only the renewal of the method of proof, but also the government's political support. the existence of institutions that are specifically engaged in efforts to eradicate corruption, and adequate regulations.

Legislation that specifically regulates corruption crimes outside the provisions of the Criminal Code is Law Number 31 of 1999 concerning Eradication of Criminal Acts of Corruption as amended and supplemented by Law Number 20 of 2001 concerning Amendments to Law Number 31 of 1999. 1999 concerning Eradication of Corruption Crimes. Law No. 30 of 2002 concerning the Corruption Eradication Commission (KPK) was also issued. The establishment of the KPK was based on the idea that corruption, which is an extraordinary crime, needs to be eradicated in extraordinary ways. Existing law enforcement institutions such as the Police, Attorney General's Office, and Judiciary Institutions are felt to have not been able to handle corruption properly, in fact they are often involved in corruption cases that are being handled. The KPK is a state institution that is independent and free from the influence of any power with the aim of increasing the efficiency and effectiveness of efforts to eradicate corruption. The legal substance factor in eradicating corruption, namely the laws and regulations as mentioned above have regulated the types of punishments that can be imposed on perpetrators of criminal acts of corruption. Article 10 of the Criminal Code stipulates that the main punishments consist 
of capital punishment, imprisonment, imprisonment, and fines. Law Number 31 of 1999 specifically stipulates the main punishment consisting of the death penalty, life imprisonment or temporary imprisonment, and fines, besides that there are also several types of additional penalties.

The Department of Law and Human Rights is a government department that takes care of everything regarding Corrections. The government provides legal services and guidance to convicts, and one form of legal service is the provision of remissions. Remission is one of the rights possessed by prisoners. 12 Remission means a reduction in the sentence that is usually given during religious holidays and independence days.

One of the considerations for granting remission is because it considers that even a prisoner is a human being and human resource who must be treated humanely in a coaching system. This inmate deserves respect and deserves a place in social interaction, and through the provision of remissions, it will accelerate the process of social reintegration of the inmates in prison, both as people of God, as individuals, and as members of society.

This Government Regulation has not been implemented effectively because the implementing provisions, namely the Presidential Regulation as mandated by Article 35 of Government Regulation Number 28 of 2006 have not been formed. Even though the Government Regulation has been included in the State Gazette and should be followed by implementing regulations so that it can be immediately implemented in Correctional Institutions, therefore the government should conduct further studies related to the policy of granting remissions for prisoners who are perpetrators of corruption.

\section{Method}

The type of research carried out in writing this thesis is adjusted to the problems raised in it, which in this case relates to remissions, which are given to prisoners who are perpetrators of corruption. The research carried out is normative juridical research, namely research that analyzes written positive law.48 Normative legal research can also be interpreted as research on legislation and legal materials related to problems in the thesis, and analyzes court decisions to see its application in practice.

In carrying out this writing, the research was carried out using library research which is the collection of data through literature or reading sources in the form of books, legislation and other reading materials related to the writing of this thesis, as well as by analyzing decisions related to the problem under study.

Data processing is essentially an activity to analyze the problems to be discussed. The data obtained will be processed using qualitative data processing methods. Qualitative research is a particular tradition in the social sciences that fundamentally relies on observing humans in their own area and dealing with these people in their language and in their terms. This qualitative analysis is then linked to relevant problems and theories so that the data obtained are descriptive, namely data arranged in the form of directed and systematic sentences to obtain a complete picture of the conclusions of what has been researched and discussed.

\section{Analysis And Results}

3.1 Legal Regulation Of The Granting Of Remissions To Criminal Criminal Acts Of Corruption In Positive Law In Indonesia

a. Development of Remission Provisions in Indonesia 
The legal basis for granting remissions has changed several times. In 1999 the government issued Presidential Decree No. 69/1999 and it has not yet been implemented but has been revoked by Presidential Decree No. 174 concerning Remissions.Change The regulations regarding remission from the Dutch era to the present are as follows:

1) Gouvernement Besluit August 10, 1935 Number 23 Bijlad Number 13515 jo. July 9, 1841 Number 12 and January 26, 1942 Number 22, Remission is a gift given solely on the birthday of the Queen of the Netherlands.

2) Presidential Decree No. 156 dated April 19, 1950 as contained in the State Gazette No. 26 Dated April 28, 1950 jo. Regulation of the President of the Republic of Indonesia Number 1 of 1946 and Regulation of the Minister of Justice of the Republic of Indonesia Number G.8/106 dated January 10, 1947 jo. Decree of the President of the Republic of Indonesia No. 120 of 1995, July 23, 1955 concerning Special Forgiveness.

3) Presidential Decree No. 5/1987 jo. Decree of the Minister of Justice of the Republic of Indonesia Number 01.HN.02.01 of 1987 concerning the Implementation of Presidential Decree Number 5 of 1987, Decree of the Minister of Justice of the Republic of Indonesia Number 04.HN.02.01 of 1988 dated May 14, 1988 concerning Additional Remissions for Prisoners Who Become Organ Donors and Blood Donors and Decree of the Minister of Justice of the Republic of Indonesia Number 03.HN.02.01 of 1988 dated March 10, 1988 concerning Procedures for Application for Change of Life imprisonment to Temporary Imprisonment based on Presidential Decree Number 5 of 1987.

4) Presidential Decree Number 69 of 1999 concerning Reduction of Criminal Period (Remission)

5) Presidential Decree No. 174/1999 jo. Decree of the Minister of Law and Legislation of the Republic of Indonesia Number M.09.HN.02.01 of 1999 concerning the Implementation of Presidential Decree Number 174 of 1999, Decree of the Minister of Law and Legislation Number M.10.HN.02.01 of 1999 concerning Delegation of Authority to Grant Special Remissions .

The provisions that are still valid until now are provisions number 5 (five), plus several provisions governing remissions, namely:

1) Decree of the President of the Republic of Indonesia Number 120 of 1955 dated July 23, 1955 concerning Special Forgiveness.

2) Decree of the Minister of Justice of the Republic of Indonesia Number 04.HN.02.01 of 1988 dated May 14, 1988 concerning Additional Remissions for Prisoners Who Become Organ Donors and Blood Donors.

3) Decree of the Minister of Law and Legislation of the Republic of Indonesia Number M.09.HN.02.01 of 1999 concerning the Implementation of Presidential Decree Number 174 of 1999.

4) Decree of the Minister of Law and Legislation Number M.10.HN.02.01 of 1999 concerning Delegation of Authority to Grant Special Remissions.

5) Circular Letter Number E.PS.01.03-15 dated 20 May 2000 concerning Changes in Life imprisonment to Temporary Imprisonment. Circular No. W8.PK.04.01-2586 dated April 14, 1993 concerning Appointment of Work Leaders.

The implementation of remission in Indonesia from time to time has changed its meaning. In the Dutch era, it was known that remission was regulated in Gauvernement Besluit Number 23 dated August 10, 1935, which was later corrected by Gauvernement Besluit Number 12 dated July 9, 1941. At that time remission was a gift, which meant it was a gift in the form of reducing the criminal period given from government to prisoners. In 1950, the rules for remission were stipulated in the Gauvernement Besluit RIS No. 156 dated April 19, 1950. This Presidential Decree stated that remission became the right of every prisoner if he met the requirements that had been set. In the era of the new order government, the Presidential Decree was perfected by 
Presidential Decree No. 5 of 1987, then in the reform era it was changed by Presidential Decree No. 69.

\section{b. Decree of the President of the Republic of Indonesia Number 5 of 1987}

In 1987, the provision regarding the acquittal for all or part of the prisoners as regulated in the Decree of the President of the Republic of the United States of Indonesia Number 156 of 1950, is considered no longer in accordance with the needs and developments of the situation. In connection with that, in the context of implementing correctional facilities in general, and improving the development of prisoners in particular, it is necessary to have a new regulation regarding the granting of a reduced period of imprisonment or remission of prisoners, then Presidential Decree Number 5 of 1987 concerning Remission was issued.

The settings are as follows:

1) Convicts who are granted remission are those who have been sentenced to more than 6 (six) months and to determine the amount of remission granted, it is calculated from the date of definite legal force.

2) The amount of remission granted is as follows: Convicts who have served a sentence; 138

a) For 6 (six) months to 12 (twelve) months, you will receive 1 (one) month remission.

b) For more than 12 (twelve) months, In the first year, he received a remission of 2 (two) months. In the second year, he received a remission of 3 (three) months. In the third year, he received a remission of 4 (four) months.In years IV and V received a remission of 5 (five) months. In year VI and onwards get a remission of 6 (six) months.

3) Life imprisonment does not get remission, unless the life sentence has been changed to a temporary sentence.

4) Criminal application lifetime life Becomes criminal temporarily carried out according to the provisions based on the request for clemency. Prisoners can also be given additional remission in addition to the usual remission above, for those who meet certain requirements

Presidential Decree Number 5 of 1987 provides many changes to the requirements for prisoners to get remission, where prisoners will get remission if they have served their sentence of at least 6 (six) months, which is much smaller than the rule in Presidential Decree Number 156 of 1950 which provides the possibility for convicts to get remission if they have served a sentence of at least 3 (three) months.

Presidential Decree Number 5 of 1987 concerning Remissions has also tightened the requirements for obtaining remissions, and also regulates the addition of remissions for prisoners who perform services to the state or humanity, or perform acts that assist the prison service. Serving the state is a service that is political in nature and is given in the struggle to maintain the survival of the state. Serving the state is a service that is political in nature and is given in the struggle to maintain the survival of the state.

Deed which are beneficial to the country or humanity, among others:

1) Produce works in advancing science and technology that are useful for development and humanity.

2) Participate in natural disasters.

3) Preventing the escape of prisoners or convicts (in some countries, escapees are subject to disciplinary punishment and are forfeited the award of reduced sentences and other prizes, but convicts who fail otherwise)

4) Become an organ donor and so on.

Presidential Decree Number 5 of 1987 only regulates the granting of remissions to prisoners with temporary sentences. Temporary punishment can be in the form of imprisonment, 
imprisonment or a substitute for a fine. Based on this, life imprisonment and death penalty cannot be given remission. He can only be given remission if the life sentence or the death penalty has been changed to a temporary prison sentence based on clemency. Regarding obtaining clemency, the prisoner concerned must apply for clemency to the President through the Minister of Justice, the decision of which can be in the form of rejection, which means that the prisoner must serve the sentence in accordance with the court's decision and secondly it is accepted which means that the sentence is changed.

Against capital punishment and life imprisonment, criminal changes are usually a level lower than the sentence imposed by the previous court, so that a convict with a death penalty, if he applies for clemency and is accepted, will be sentenced to life imprisonment. The possibility of the death penalty turning into a temporary punishment because the clemency is accepted (down two levels) is possible, but it is very difficult to expect. For prisoners with life imprisonment who apply for clemency and are accepted, the clemency decision will change from a life sentence to a temporary sentence.

The process of changing the death penalty and life imprisonment through clemency carried out by the inmate will make it less likely for him to get remission again, because the change is already a maximum remission, therefore for those who are sentenced to death actually only have 2 (two) options, namely : Remain in the form of a death penalty and immediately undergo the execution of the death penalty. Changes to a life sentence if the clemency is accepted, which means delaying death, thus a person sentenced to death is very unlikely to be able to get out of the Correctional Institution, because the regulations for that are already limited. Once again, it is possible to change the death penalty to a temporary punishment through clemency, but it is unlikely.

\section{c. Presidential Decree No. 69/1999}

The provisions regarding the reduction of the criminal period which had previously been regulated in the Presidential Decree of the Republic of Indonesia Number 5 of 1987 concerning Reduction of the Period of Criminal Serving (Remission) were then adjusted again in connection with the issuance of the provisions in Law Number 12 of 1995 concerning Corrections and Law Number 3 of 1997 concerning Juvenile Court. This adjustment was made with the stipulation of Presidential Decree No. 69/1999 on Remissions.

The settings are as follows:

1) Convicts and criminal children who are given remission are those who have been sentenced to more than 6 (six) months.

2) The calculation of the length of serving the sentence is calculated from the date of detention.

3) The amount of remission granted is as follows: Convicts who have served a sentence;

4) For 6 (six) months to 12 (twelve) months, you will receive 1 (one) month remission.

5) For more than 12 (twelve) months,

6) Convicts and criminal children can also be given additional remission in addition to the usual remission as mentioned above, if they meet certain requirements,

7) Convicts for life and have served their sentence for at least 5 (five) consecutive years can be changed to a temporary prison sentence, so that the length of the remaining sentence that still has to be served becomes a maximum of 15 (fifteen) years.

8) The change from life imprisonment to temporary punishment is stipulated by the Decree of the Minister of Justice of the Republic of Indonesia on the anniversary of the Proclamation of Independence of the Republic of Indonesia on 17 August.

Presidential Decree Number 69 of 1999 stipulates that convicts who are sentenced to life imprisonment and have served their sentence for at least 5 (five) consecutive years and are of 
good behavior can be changed from life imprisonment to temporary imprisonment so that the remaining length of the sentence remains must be served for a maximum of 15 (fifteen) years. The determination of the change from life imprisonment to temporary imprisonment is sufficient by the Decree of the Minister of Justice of the Republic of Indonesia which was announced on August 17, right on the celebration of the Independence Day of the Republic of Indonesia.

Presidential Decree Number 69 of 1999 is almost the same as the regulations in force in Japan, Argentina and Korea where in these countries prisoners who are sentenced to life imprisonment after serving several years of their sentence can get remission and even get conditional release without asking for clemency from the head of state, as long as during the allotted time they behave well.

Canada does not even recognize a life sentence in its punishment, so remission can be given to every convict on the condition that the convict in question is considered to have successfully served his sentence. Granting remission in Canada is based on the Corrections and Conditional Release Act. This specializes in the duties of prison authorities as parole Board to assess every prisoner who is entitled to remission.

In Canada, the granting of remission is made under the Queen's Printer Act No. RSEI 1988, Cap. 0-1 and the Prison Act and Reform. Federal law of Canada grants automatically remission after serving $1 / 3$ (one third) of the sentence.Prisonersno criminal reduction or remission is given if:

1) Not doing or refusing to actively undergo coaching programs and work activities in prison.

2) Violating prison regulations (violate the zero tolerance policy) against officers.

3) Not adhering to standards of behaving in a positive manner.

d. Presidential Decree No. 174/1999

This Presidential Decree No. 174/1999 was issued as an implementing regulation of Government Regulation No. 32/1999 on the Terms and Procedures for the Implementation of the Rights of Prisoners. Remission is one of the rights of convicts and criminal children as mandated by Article 14 of Law Number 12 of 1995 concerning Corrections, and this is reaffirmed in Article 34 of Government Regulation Number 32 of 1999.

Additional remissions are given regarding the day of the Proclamation of Independence of the Republic of Indonesia on August 17 to those who because of their abilities and/or skills have provided education and teaching to fellow prisoners and students. The abilities and skills taught must be useful for the future of prisoners and correctional students. The amount of this additional remission is the same as the additional remission given to leaders.

Additional remissions are also given to prisoners who are organ donors and blood donors. Based on the Decree of the Minister of Justice of the Republic of Indonesia Number 04.HN.02.01 of 1988 dated May 14, 1988 concerning Additional Remissions for Prisoners Who Become Body Organ Donors and Blood Donors, every convict who is serving a temporary sentence, either imprisonment, confinement or criminal punishment in lieu of a fine can be proposed for remission if you become an organ donor and/or blood donor.

The proposal for additional remission must be accompanied by a valid proof or certificate issued by the hospital carrying out the organ donation operation or by the Indonesian Red Cross (PMI) carrying out the blood collection. Proposals for additional remissions that are not accompanied by evidence or certificates will be rejected. The enactment of the Decree of the President of the Republic of Indonesia Number 174 of 1999 grants two remissions within one year, namely general remissions and special remissions. Giving This two-time remission is not 
intended as a convenience in the policy of serving a sentence so as to reduce the meaning of punishment, but for:

1) It is more motivating and used as a tool to improve the ability of prisoners and criminal children to behave well continuously in order to accelerate the process of social reintegration in question.

2) In line with the Correctional function as an integral part of the criminal justice system in the criminal justice system, the granting of remissions is an effort to reduce the negative impacts and sub the culture of the place where the crime is carried out, the criminal disparity and the consequences of deprivation of liberty.

3) Psychologically, giving remissions has the effect of suppressing the level of frustration (especially for recidivist prisoners) so that it can reduce or minimize disturbances to security and order in the Correctional Institution or Detention Center in the form of escapes, fights and other riots.

4) Special remissions given during religious holidays are expected to be a catalyst for correctional inmates to achieve self-awareness which is reflected in good attitudes and behavior in accordance with religious demands in their daily lives.

5) Changes in life imprisonment to temporary punishment are given in the context of implementing the rights of prisoners sentenced to life imprisonment to improve themselves and have the hope of returning to the midst of society through the correctional process as other prisoners.

Based on the Decree of the Minister of Justice and Human Rights No. M.01.HN.02.01 of 2002, as a form of protection for convicts and criminal children in the promotion and protection of human rights based on the penitentiary system and to reflect equity in order to give a sense of justice to those entitled to it, it has been regulated to grant a special delayed remission, conditional special remission and additional remission. The difference between pending special remission and conditional special remission is:

1) Delayed special remission is a special remission given to convicts and criminal children whose implementation is carried out after the person concerned has the status of a prisoner and the maximum amount is 1 (one) month.

2) Conditional special remission is a special remission that is given conditionally to convicts and criminal children who during religious holidays have not had enough 6 (six) months to serve their sentence. For convicts and juvenile delinquents, a special conditional remission can be proposed, if during the 6 (six) month conditional period the person concerned continues to behave well. This conditional special remission can be revoked if within the required period it turns out that the person concerned has committed a disciplinary violation.

The development of provisions for granting remissions, as seen from the above discussion, continues to change from time to time in line with the transfer of power from the government. The granting of this remission is also related to a historic big day for the Indonesian people, for example, the granting of remissions every commemoration of the Republic of Indonesia's independence day every August 17. This gives a warning that the independence that the Indonesian people got on August 17, 1945 was a milestone in the struggle that the heroes had achieved not easily, but with the sacrifice of property and lives.

The independence obtained by prisoners is also something that is expensive in value, therefore only prisoners who are well behaved are given a cut in punishment as a reward for those who have behaved well while serving their sentence. ${ }^{162}$ The amount of remission at this time when compared to the provisions of the previous regulations is smaller. In the 1950s remissions were given for a minimum of 1 (one) month and a maximum of 9 (nine) months, and the remission was given to prisoners who had served a sentence of at least 3 (three) months. During the post1998 reform period, the reduction in the criminal period was amended by Presidential Decree No. 174/1999 on Remissions. Through this regulation, apart from a general remission every 17 
August, special remissions are also given on every religious holiday that is embraced by prisoners. The amount of general remission does not differ from the provisions of Presidential Decree Number 5 of 1987.

The procedure for applying for remission is submitted to the Minister of Law and Human Rights of the Republic of Indonesia by the Head of the Correctional Institution, through the Head of the Regional Office of the Ministry of Law and Human Rights of the Republic of Indonesia. The Decree of the Minister of Law and Human Rights of the Republic of Indonesia concerning Remissions states that the granting of remissions to prisoners and criminal children at the commemoration of the Proclamation of Independence of the Republic of Indonesia on August 17 for those who are given general remission or on religious holidays adhered to by the prisoners and criminal children concerned, if there are doubts about the day of the number of religions adopted by convicts or criminal children, the Minister of Law and Human Rights may consult with the Minister of Religion.

The method of recording the remission is based on the form or type of remission and must be recorded in a separate register. ${ }^{166}$ The proposal for remission is attached with excerpts from the court's decision, a warrant for criminal execution (execution) from the prosecutor's office, a warrant for detention from the police, a list of changes to the calculation of the date of release (expiration), as well as a coaching card or good behavior for prisoners. The remission proposal was made in duplicate, each addressed to the Regional Office of the Ministry of Law and Human Rights and the Directorate General of Corrections.

\subsection{Legal Rules for Granting Remissions to Convicts of Corruption Crimes in Positive Law in Indonesia}

Penitentiary is one part of the Criminal Justice System (Criminal Justice System) which contains a systemic movement of its supporting subsystems, namely: Police, Prosecutors, Courts and Correctional Institutions (Penitentiary) which as a whole constitute a unity (totality) which trying to transform inputs (inputs) into outputs (outputs) which are the goals of the Criminal Justice System in the form of resocialization of criminals (short term), prevention (medium term) and social welfare (long term).

In line with that, correctional activities are a way of implementing prison sentences in the form of a conversion process system that involves interrelationships, interactions and integrity between community components and law enforcement components who carry out the coaching process for prisoners components, with the aim of producing coaching someone to become a good and useful citizen. in society. The correctional system becomes an open system that has an input component of prisoners in the coaching process and the results of coaching become a useful citizen (output) back to being part of a good society. The same applies to granting remissions, and even clemency to Syaukani Hasan Rais, the former regent of Kutai Kertanegara, who was called the richest regent in Indonesia for committing corruption that cost the state Rp. 113,000,000,000, - (one hundred and thirteen billion rupiah), received a reaction in the form of a big rejection from the public who felt that their sense of justice was disturbed.

Based on all of the above explanation, it can be stated that remission as a right of prisoners whose existence is guaranteed by Law Number 12 of 1995 concerning Corrections may not be removed for convicts of criminal acts of corruption only because it is based on pressure from the community who wants that perpetrators of corruption should be punished severely. the weight. Remissions, however, must be given with due consideration in accordance with the applicable regulations, namely Government Regulation Number 28 of 2006, with implementing regulations that must be issued immediately so that this regulation can provide more legal certainty. The granting of remissions must also be accountable and not injure the community's sense of justice. 
In this regard, it must be kept in mind that the idea and purpose of the penitentiary itself is to rehabilitate and resocialize prisoners through educative, corrective and defensive actions, not just to punish and provide a deterrent effect by providing a long sentence. Until now, Correctional Institutions have not shown optimal results in carrying out their duties to provide guidance to prisoners, and there is no significant correlation between the length of criminal sanctions and the reduction in the number of people who commit crimes. In the end, the government's decision to increase the requirements for granting remissions to convicts of criminal acts of corruption, if it is not followed by improvements or reforms of the guidance system in the Correctional Institution and its legal instruments, will not reap maximum results.

\section{Conclusion}

The basis for granting remissions to convicts who commit corruption crimes is to motivate convicts of criminal acts of corruption to behave well, then speed up convicts with good behavior so that they can be released and re-integrate into society before the actual date of freedom. The penitentiary system that adheres to the theory of the purpose of an integrative punishment, means that punishment does not only contain deterrence aspects, but also aspects of coaching and improvement. The correctional system tries to foster and correct the mistakes of the prisoners and then realize their social reintegration, and remission is one of the tools to see the success of the coaching.

The legal arrangement for granting remissions to convicts who are guilty of corruption in positive law in Indonesia refers to Government Regulation Number 28 of 2006 concerning Amendments to Government Regulation Number 32 of 1999 concerning Conditions and Procedures for the Implementation of the Rights of Correctional Inmates. This new regulation contains provisions for granting remissions that are different from the previous provisions, namely for prisoners who are perpetrators of criminal acts of corruption involving law enforcement officers, state administrators, and other people who are related to corruption crimes committed by law enforcement officers or state officials. receive attention that disturbs the public, or involves a state loss of at least Rp. 1,000,000,000,- (one billion rupiah), must meet the following requirements: Good behavior.

\section{References}

Amiruddin, and Zainal Asikin, Introduction to Legal Research Methods. Jakarta: PT. Raja Grafindo Persada, 2004.

Arief, Barda Nawawi, Capita Selecta on Criminal Law. Bandung: Citra Aditya Bakti, 2003.

Criminal Law Policy, Development of Drafting of the New Criminal Code Concept, Jakarta : Kencana Prenada Media Group, 2008.

Black's Law Dictionary, 1990.

Chaerudin, Syaiful Ahmad, and Syarif Fadillah, Strategies for Prevention and Eradication of Corruption Crimes. Bandung: Refika Aditama, 2008.

Gunakaya, A. Widiada, History and Conception of Corrections. Bandung : Armico, 1995. Hamzah, Andi, Legal Dictionary. Jakarta: Ghalia Indonesia, 2000.

Eradication of Corruption Through National and International Criminal Law. Jakarta : Raja Grafindo Persada, Revised Edition, 2007.

---------, Indonesian Criminal Procedure Code. Jakarta: Sinar Graphic, 2000. 
A Brief Objective of the Criminal System in Indonesia. Jakarta: Akademika Pressindo, 1983.

Harsono, CI, New System for Convict Guidance. Jakarta: Djambatan, 1995. Hartanti, Evi, Corruption Crimes. Semarang: Sinar Graphic, 2005.

----------, Corruption Crime Second Edition. Jakarta: Sinar Graphic, 2007.

Ibrahim, Idy Sybandy and Drs. Yosal Iriantara, Fighting Corruption in the Public Sector. Bandung: Sawarung, 2003.

Lamintang, PAF, Indonesian Penitentiary Law. Bandung: Armico, 1984.

Lopa, Baharuddin, Corruption Crimes and Law Enforcement, Jakarta: Rineka Cipta Publisher, 1992.

Lubis, Solly, Law Politics. Bandung: Mandar Maju, 1989.

Makarim, Edmon, Compilation of the Law of Telematics. Jakarta : PT Raja Grafindo Persada, 2003.

Mertokusumo, Sudikno, Prof. Dr., Know Law Something Introduction. Yogyakarta: liberty, 2003.

MD, Mahfud, Political Law in Indonesia. Jakarta : LP3ES, 1998.

Moleong, Lexy J, Qualitative Research Methodology. Bandung : Remadja Karya, 1989.

Muladi, Conditional Criminal Institution. Bandung : Alumni, 2004. hlmn. 117.

---------, Capita Selecta of the Criminal Justice System. Semarang: Diponegoro University, 2004.

Muladi and Barda Nawawi Arief, Criminal Theories and Policy. Bandung : Alumni, 1998.

Mulyadi, Lilik, Compilation of Criminal Law in Theoretical Perspectives and Judicial Practice. Bandung: Mandar Maju, 2010.

Mulyadi, Mahmud, Criminal Policy, Integral Approach and Non-Penal Policy in Combating Violent Crimes. Medan: Pustaka Bangsa Press, 2008.

Mulyadi, Mahmud and Ferri Antoni Surbakti, Politics of Criminal Law Against Corporate Crime. Jakarta : Softmedia, 2010.

Napitupulu, Diana Ria Winanti, KPK In Action. PT Niaga Swadaya, 2010.

Ohoitimur, Yong, Ethical Theory of Legal Punishment. Jakarta : Gramedia Pustaka Main, 1997.

Panjaitan, Petrus Irwan and Chairijah, Prison Criminals in the Perspective of Law Enforcement, Society and Prisoners. Jakarta : Radar Jaya, 2008.

Panjaitan, Petrus Irwan and Samuel Kikilaitety, Where to go for prison sentences. Jakarta: Indhill Co., 2007.

Prasetyo, Teguh and Abdul Halim Barkatullah, Politics of Criminal Law,Policy Studies on Criminalization and Decriminalization. Yogyakarta: Student Library, 2005.

Priyatno, Dwidja, Implementing Prison Criminal System in Indonesia. Jakarta: Refika Aditama, 2006.

Poernomo, Bambang, Capita Selecta Criminal Law. Yogyakarta : Liberty, 1988.

---------, Implementation Criminal Jail With System Correctional. Yogyakarta : Liberty, 1986.

Poerwadarminta, WJS, General Indonesian Dictionary, Publisher: Balai Pustaka, 1976. 
Reksodiputro, Mardjono, Human Rights in the Criminal Justice System: Third Book Collection. Jakarta: Center for Justice and Legal Services, University of Indonesia, 1994.

Sanusi, A. Fundamentals of Penology. Jakarta: Rasanta, 1994.

Salim, Bachtiar Agus, Imprisonment in the Criminal System in Indonesia. Medan : USU Press, 2009.

Saleh, Roeslan, Indonesian Criminal Stelsel. Jakarta : New Aksara, 1989 Sholehuddin, M, Sanction System in Criminal Law, Basic Idea of Double Track System and its implementation. Jakarta : Raja Grafindo Persada, 2007.

Soemitro, Ronny Hanitijo, Legal and Jurimetric Research Methodology, Ghalia Indonesia, Jakarta, 1990. Sudarto, Capita Selecta Criminal Law. Bandung : Alumni, 1986.

---------, Law and Criminal Law. Bandung : Alumni, 1981.

---------, Criminal Law and Community Development: A Study of Criminal Law Reform. Bandung: Sinar Baru, 1983.

Soekanto, Soerjono, and Sri Mamudji, Normative Legal Research SomethingOverview Short, Jakarta: PT. Radja Grafindo Persada, 2007.

Supomo, Chapters on Customary Law. University Publishers, 1963.

Herjana, Endang, Implementation Strategy for Convicts for Corruption Crimes. Papers, UI, Jakarta, 2001.

Katono, Basuki, Granting Remissions for Convicts of Narcotics- $\backslash$ Psychotropic Crimes, Corruption, Terrorism, and Serious Human Rights Crimes. Jakarta: Papers, UI, 2007.

Mulyadi, Mahmud, Politics of Criminal Law. USU Faculty of Law Lecture Materials, Medan, 2010.

Nugroho, Yuliawan Dwi, Efforts to Overcome Overcrowding in State Detention Centers and Correctional Institutions in DKI Jakarta. Papers, UI, 2008.

Subroto, Dalil Adi, Guidance of Prisoners as a Means of Realizing the Criminal Goals of Correctional Institutions. Papers in the National Seminar on Corrections, Cooperation with the Criminal Department, Department of Events and the Laboratory of the Faculty of Law UII, Yogyakarta. July 24, 1995.

Sudirman, Didin, Actual Problems in the Correctional Sector. Paper, at the Center for Policy Assessment and Development of the Indonesian Ministry of Law and Human Rights, Jakarta, 2006.

Sitanggang, Tati Vain, The Dilemma of Imprisoning Life in Prison Against Perpetrators of Criminal Acts of Corruption. Papers, UI, 2008.

Zulfikri, Obstacles Faced by Correctional Institutions on the Lack of Guidance for Convicts in Corruption Cases. Papers, UI, 2007.

Presidential Decree Number 5 of 1987 concerning Remissions Presidential Decree Number 69 of 1999 concerning Remissions. Presidential Decree No. 174/1999 on Remissions.

Decree of the President of the Republic of Indonesia Number 174 of 1999 concerning Remissions

Law of the Republic of Indonesia Number 30 of 2002 concerning the Corruption Eradication Commission.

Law Number 31 of 1999 concerning the Eradication of Criminal Acts of Corruption as amended and supplemented by Law Number 20 of 2001 concerning Amendments to Law Number 31 of 1999. LN No. 140 of 1999, TLN No. 3874. 
Directorate of Registration and Statistics Directorate General of Corrections Ministry of Law and Human Rights RI, Jakarta.

www.udin.mahkamahagung.go.id,Court Decision Directory great Republic Indonesia.

http://www.canadianprisonlaw.com/pra/camed.htm, last accessed on January 20, 2010.

http://www.oasis.com, Ireland Community, last accessed on 20 December 2010.

http:www.oneworld.org/news/reports/un97_gutman.html, last time accessed on December 212010.

www.indonesia.go.id/index2.php?option=com , last accessed on date 7 September 2010.

http://www.miftakhulhuda.com/2010/11/penjara-dan-politik- criminal.html, last times accessed on Friday, November 262010.

www.infokorupsi.com, last accessed on Thursday, August 19, 2010. http://national.kompas.com/read, last accessed on 26 September 2010.

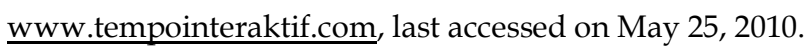

http://www.tempointeraktif.com/hg/opiniKT/2011/01/13, last accessed on Thursday, January 13, 2011. www.forum.net, last accessed on Sunday, January 22, 2011.

http://www.korantempo.com/korantempo/koran/2010/08/18/, final time in access on Sunday, January 222011. 